\title{
Iatrogenic Damage to the Periodontium Caused by Fixed Prosthodontic Treatment Procedures
}

\author{
PV Harish ${ }^{1}$, Sonila Anne Joseph ${ }^{2, *}$, Syed Sirajuddin ${ }^{3}$, Veenadharini Gundapaneni ${ }^{3}$, \\ Sachidananda Chungkham ${ }^{3}$ and Ambica ${ }^{3}$
} ${ }^{I}$ Department of Prosthodontics, Rajarajeswari Dental College \& Hospital, Bangalore, Karnataka, India; $;{ }^{2}$ Dental
Art Clinic, Mareena towers, Coastal Road, Mahaboula, Kuwait; ${ }^{3}$ Department of Periodontology, Rajarajeswari Dental
College \& Hospital, Bangalore-560074, Karnataka, India

\begin{abstract}
Missing teeth should be replaced as soon as possible to maintain arch integrity and thereby avoid both morphologic and functional derangements in the occlusion. Otherwise, changes occur that upset the masticatory system, such as extrusion of the teeth opposing the edentulous areas along with their alveolar housing, their supporting tissues and ultimately the maxillary sinus. Concurrently with extrusion, shifting of the interproximal contacts and migration of the adjacent teeth occur, thereby impairing function and causing disharmony. Good oral health cannot be achieved when changes in tooth position alter the coronal contour and occlusion interfering with mutual support, which encourages food impaction and retention, further leading to osseous defects.
\end{abstract}

Keywords: Crown, fixed prosthodontic treatment, iatrogenic damage, periodontium, fpd.

\section{INTRODUCTION}

Teeth are prepared to receive crowns and restorations, and these preparations must be based on important doctrine from which basic criterion can be established to aid in calculating the achievement of prosthodontics management.

Careful attention to every detail is imperative during tooth preparation.

A good preparation will make sure that succeeding techniques (e.g., provisionalization, impression making, pouring of dies and casts, waxing) can be accomplished. The principles of tooth preparation may be divided into three broad categories: (Fig. 1).

1. Biologic considerations - which affect the health of the oral tissues.

2. Mechanical considerations - which affect the integrity and durability of the restoration.

3. Esthetic considerations - which affect the appearance of the patient.

\section{OPTIMAL RESTORATION}

Effective tooth preparation and restoration depend on simultaneous consideration of all these factors. Often improvement in one area will adversely affect another, and trying for perfection in one may lead to failure in another. For example, in the fabrication of a metal-ceramic crown, sufficient thickness of porcelain is necessary for a lifelike appearance. However, if too much tooth structure is removed to

*Address correspondence to this author at the $1^{\text {st }}$ Floor, Mareena towers, Coastal Road, Mahaboula, Kuwait; Tel: 0096566206465;

E-mail: josephsonila@gmail.com accommodate a greater thickness of porcelain for esthetic reasons, the pulpal tissue may be damaged (biologic consideration) and the tooth unduly weakened (mechanical consideration). An in-depth knowledge and understanding of various criteria are prerequisites to the development of satisfactory tooth preparation skills.

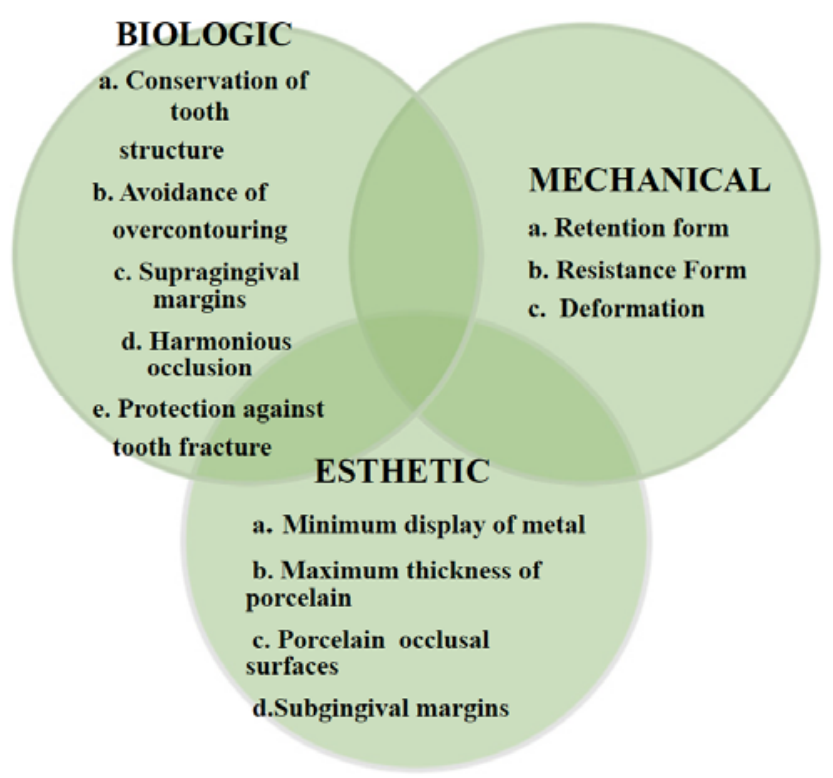

Fig. (1). The optimum restoration should satisfy biologic, mechanical, and esthetic requirements.

\section{BIOLOGIC CONSIDERATIONS}

Surgical procedures involving living tissues must be carefully executed to avoid unnecessary damage. The adja- 
cent teeth, soft tissues, and the pulp of the tooth being prepared are easily damaged in tooth preparation. If poor preparation leads to inadequate marginal fit or deficient crown contour, plaque control around fixed restorations will become more difficult. This will impede the long-term maintenance of dental health.

\section{Iatrogenic Damage During Tooth Preparation}

\section{Adjacent Teeth}

Iatrogenic damage to an adjacent tooth is a common error in dentistry. Even if a damaged proximal contact area is carefully reshaped and polished, it will be more susceptible to dental caries than the original undamaged tooth surface. This is presumably because the original surface enamel contains higher fluoride concentrations and the interrupted layer is more prone to plaque retention. The technique of tooth preparation must avoid and prevent damage to the adjacent tooth surfaces.

A metal matrix band around the adjacent tooth for protection may be helpful; however, the thin band can still be perforated and the underlying enamel damaged. The preferred method is to use the proximal enamel of the tooth being prepared for protection of the adjacent structures. Teeth are 1.5 to $2 \mathrm{~mm}$ wider at the contact area than at the cementoenamel junction (CEJ), and a thin, tapered diamond can be passed through the inter proximal contact area (Fig. 2) to leave a slight lip or fin of enamel without causing excessive tooth reduction or undesirable angulation of the rotary instrument.

\section{Iatrogenic Damage to the Soft Tissues}

Damage to the soft tissues like the tongue and the cheek occurs during tooth preparation. Damage to the cheeks and the lips occurs during preparation of the labial and buccal surfaces and damage to the tongue occurs when the lingual surfaces of mandibular molars are being prepared. Damage to the soft tissues of the tongue and cheeks can be prevented by careful retraction with an aspirator tip, mouth mirror, or flanged saliva ejector. Great care is needed to protect the tongue when the lingual surfaces of mandibular molars are being prepared.

\section{Iatrogenic Damage to the Pulp}

Pulpal degeneration occurs during or after tooth preparation, especially complete crown preparation. Great care is also needed to prevent pulpal injuries during fixed prosthodontics procedures. Pulpal degeneration that occurs many years after tooth preparation has been documented [1, 2], particularly when they occur on freshly sectioned dentinal tubules. Prevention of pulpal damage necessitates selection of techniques and materials that will reduce the risk of damage while preparing tooth structure [1].

Tooth preparations must take into consideration the morphology of the dental pulp chamber. Pulp size, which can be evaluated on a radiograph, decreases with age. Average pulp dimensions have been related to the coronal contour [2].

The utmost biologic threat happens while inserting into sub gingival boundaries [3]. These boundaries are not as manageable as supragingival or equigingival margins for concluding procedures. In toting up, if the margin is located too far below the gingival tissue crest, it will disturb the gingival attachment apparatus.

Biologic width is the dimension of space that the healthy gingival tissues occupy above the alveolar bone. Gargiulo, Wentz, and Orban's in 1961, were the authors who did the earlier studies on cadavers establishing the dimensions of space required by the gingival tissues [4]. In an average human, the connective tissue attachment occupies $1.07 \mathrm{~mm}$ of space above the crest of the alveolar bone, and that the junctional epithelial attachment below the base of the gingival sulcus occupies another $0.97 \mathrm{~mm}$ of space higher than the connective tissue attachment. The blend of these two measurements is the "biologic width" (Fig. 3).

Clinically, this information is helpful to identify biologic width violations when the restoration margin is placed $2 \mathrm{~mm}$ or less away from the alveolar bone and the gingival tissues are inflamed.

Placement of restoration margins below the gingival tissue crest was decided by restorative considerations. Restorations may need to be extended gingivally.

(1) To make appropriate resistance and retentive form in the preparation,
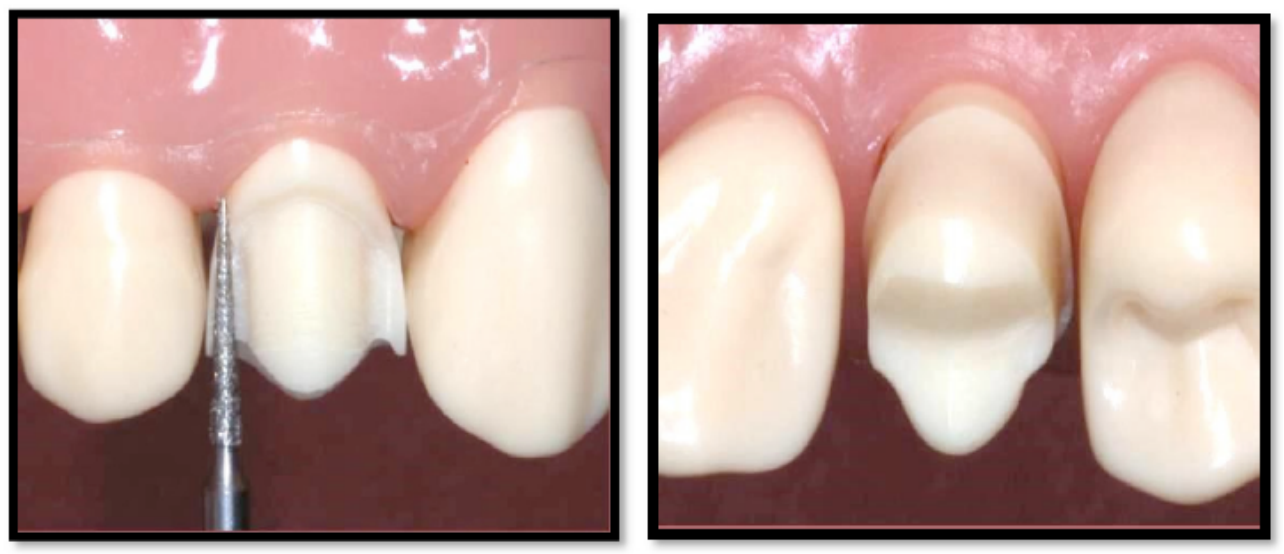

Fig. (2). Damage to adjacent teeth is prevented by making a thin "lip" of enamel as the bur passes through a proximal contact. 
(2) To make important contour alterations due to caries or other tooth deficiencies, or

(3) To cover the tooth/restoration interface by locating it subgingivally. When the restoration border is placed far below the gingival tissue crest, it will create a violation of biologic width and impinge on the gingival attachment apparatus [5]. Two different responses can be observed from the concerned gingival tissues (Fig. 4).

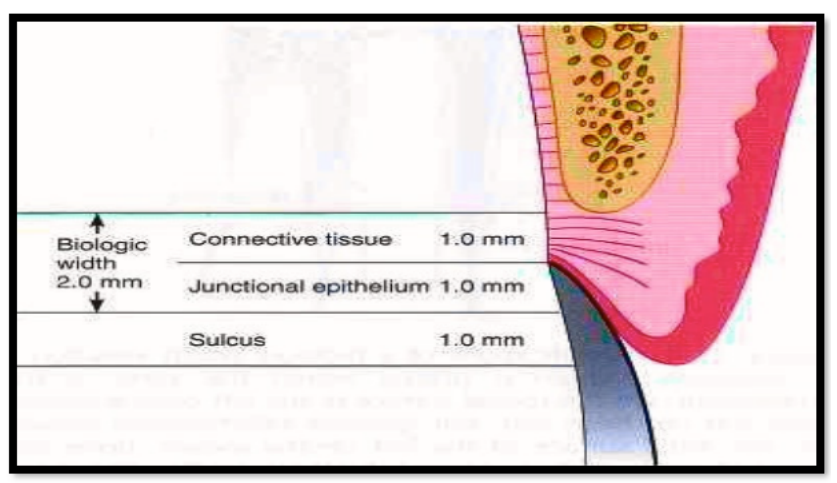

Fig. (3). Average human biologic width: Connective tissue attachment $1 \mathrm{~mm}$ in height; junctional epithelial attachment $1 \mathrm{~mm}$ in height; sulcus depth of approximately $1 \mathrm{~mm}$. The combined connective tissue attachment and junctional epithelial attachment, or biologic width, equals $2 \mathrm{~mm}$. biologic width.

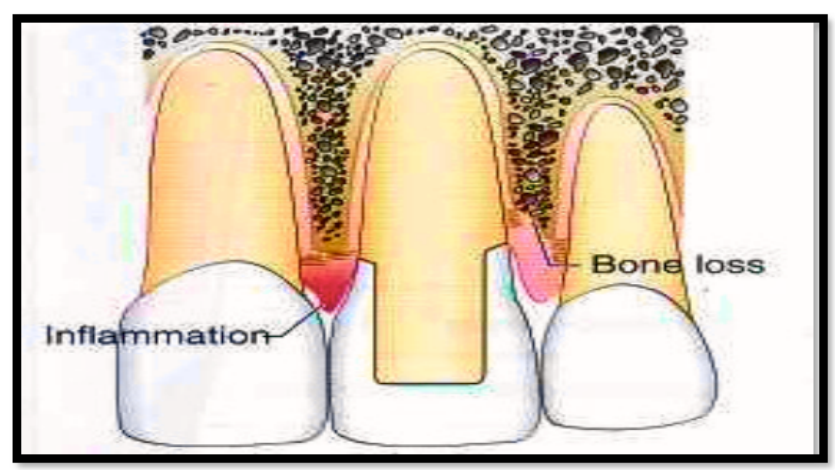

Fig. (4). Consequences of a biologic width violation if a restorative margin is placed within the zone of the attachment. On the mesial surface of the left central incisor, bone has not been lost, but gingival inflammation occurs. On the distal surface of the left central incisor, bone loss has occurred, and a normal biologic width has been reestablished.

One likelihood is that gingival tissue recession along with bone loss of an unpredictable nature will occur as the body attempts to recreate space between the alveolar bone and the margin to allow space for tissue reattachment. This occurs most commonly in areas where the alveolar bone surrounding the tooth is very thin in width. Trauma from restorative procedure scan play a key function in causing this delicate tissue to move away. Other factors that may influence the likelihood of recession include

(1) Whether the gingiva is thin and fragileor thick and fibrotic

(2) Whether the gingival form is flat or highly scalloped. It has been found that recession occurs more commonly in highly scalloped thin gingiva than a flat periodontium with thick fibrous tissue [6].

The more frequent finding with deep margin placement is that gingival inflammation develops and persists even though the bone level appears to remain unchanged. Hence it is important to establish space between the alveolar bone and the restorative margin to restore gingival tissue health. This can be accomplished either by surgery to change the bone level or by orthodontic extrusion to move the restoration margin farther away from the bone level.

Violation of the biologic width becomes of particular concern when considering. If the restoration of a tooth has fractured or if it has been destroyed by caries near the alveolar crest level. Also, esthetic demands often require "burying', of restorative margins subgingivally, which can lead to violation of this space. To avoid deleterious effects various authors have recommended that the restorative margins must be of minimal distances from the bone crest. To permit adequate healing and restoration of the tooth, Ingber et al. [7] recommended that a minimum of $3 \mathrm{~mm}$ was necessary from the restorative margin to the alveolar crest.

The periodontium was divided into three dimensions by Maynard \& Wilson as: superficial physiologic, crevicular physiologic, and subcrevicular physiologic [8].

(i) The free and attached gingiva adjacent the tooth is the superficial physiologic dimension, (ii) the gingival crevice extending from the free gingival margin to the junctional epithelium is the crevicular physiologic dimension. (iii) The subcrevicular physiologic space is similar to the biologic width described by Gargiulo et al., consisting of the junctional epithelium and connective tissue attachment [9]. Maynard \&Wilson claimed that the clinician should 'conceptualize' all three areas as all three of these dimensions affect restorative management decisions [8].

In particular the authors claimed that to prevent the placement of 'permanent calculus' beyond the crevice margin, placement of margins into the subcrevicular physiologic space should be avoided. Nevins \& Skurow stated that when subgingival margins are indicated, the junctional epithelium or connective tissue apparatus must not be disrupted during restorative preparation and impression taking [10].

It is for the difficult clinician to identify of the sulcular epithelium ends and the junctional epithelium begins and hence the authors recommend to limit the extension of subgingival margin to $0.5-1.0 \mathrm{~mm}$. They also emphasized allowing a minimum $3.0 \mathrm{~mm}$ distance from the alveolar crest to the crown margin. The free gingival margin has been suggested as the reference point for measurements for margin placement as the biologic width is difficult for the clinicians to picture [11]. Block stated that surgical crown-lengthening procedures are essential when restorative margins end at or near the alveolar crest level. However, it appears that a minimum of $3 \mathrm{~mm}$ of space between restorative margins and alveolar bone is a dimension that is to adhere to in restorative treatment planning.

In some patients if the margins are located more than 2 $\mathrm{mm}$ above the alveolar bone it will violate the biologic width. In 1994, Vacek et al. also examined the biologic width phenomenon [12]. Although their average width find- 
ing of $2 \mathrm{~mm}$ was the same as formerly reported by Gargiulo et al. (Fig. 5) [13]. They also reported a range of different biologic widths that were specific to some patients. They described biologic widths as narrow as $0.75 \mathrm{~mm}$ in some individuals, whereas others had biologic widths as high as $4.3 \mathrm{~mm}$ (Fig. 6) [14].

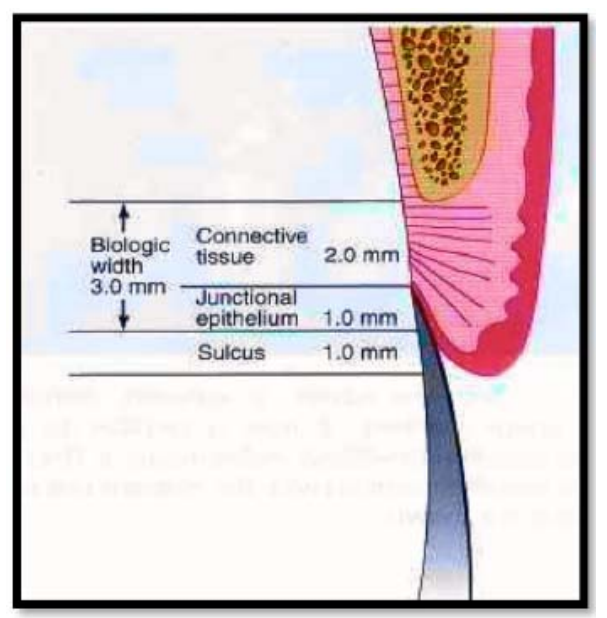

Fig. (5). Possible disparities exist in biologic width. Connective tissue attachments and junctional epithelial attachments may be variable. In this example the connective tissue attachment is $2 \mathrm{~mm}$ in height, the junctional epithelial attachment $1 \mathrm{~mm}$ in height, and the sulcus depth $1 \mathrm{~mm}$, for a combined total tissue height above bone of $4 \mathrm{~mm}$. However, the biologic width is $3 \mathrm{~mm}$. This is just one variation that can occur from the average.

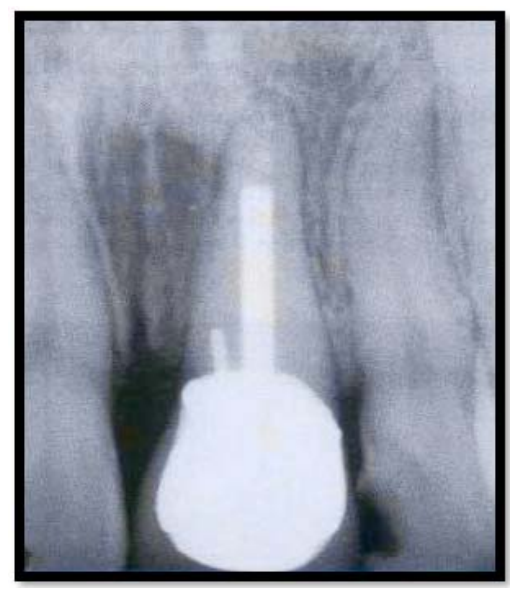

Fig. (6). Radiograph shows a biologic width violation on the mesial surface interproximally. Removal of interproximal bone would produce an esthetic deformity.

\section{CONSIDERATIONS AFFECTING FUTURE DENTAL HEALTH}

An improperly prepared tooth may have an adverse effect on long-term dental health. For example, insufficient axial reduction inevitably results in an over contoured restoration that hampers plaque control. This may cause periodontal disease or dental caries. Alternatively, inadequate occlusal reduction may result in occlusal dysfunction, and poor margin placement may lead to chipped enamel or cusp fracture [15].

\section{Axial Reduction}

Gingival inflammation is commonly associated with crowns and FPD abutments having excessive axial contours, probably because it is more difficult for the patient to maintain plaque control around the gingival margin [16]. A tooth preparation must provide sufficient space forthedevelopment of good axial contours (Fig. 7). This will enable the junction between the restoration and the tooth to be smooth and free of any ledges or abrupt changes in direction (Fig. 8).

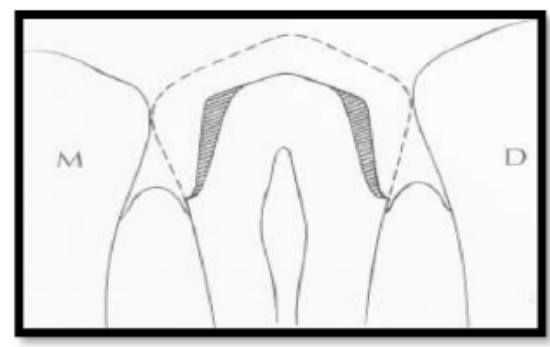

Fig. (7). Excessive taper results in considerable loss of tooth structure (shaded area). BC
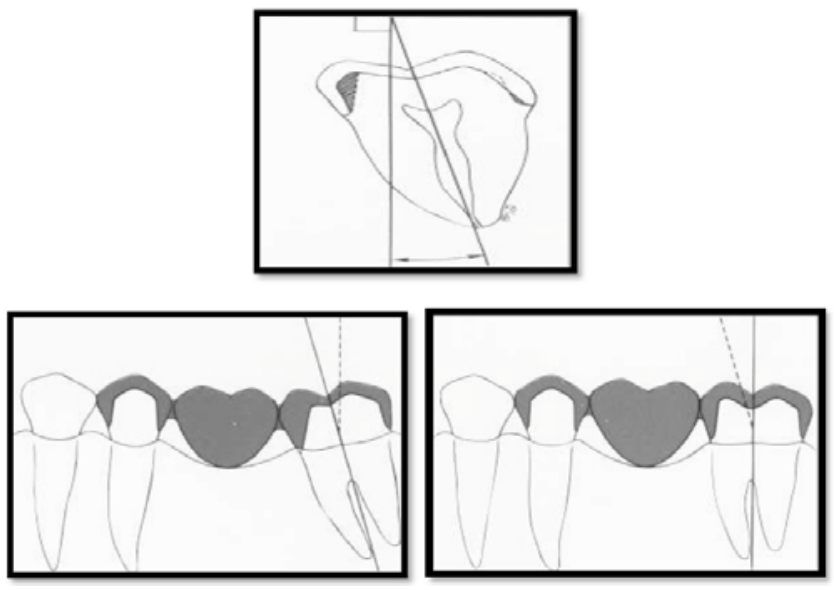

Fig. (8). To conserve tooth structure, the preparation of axial surfaces should be as uniform as possible. A, The path of withdrawal should coincide with the long axis of the tooth, which for a mandibular premolar is typically inclined 9 degrees lingually. Preparing the tooth perpendicular to the occlusal plane is a commonly seen error and results in additional tooth reduction (shaded area). B and $\mathrm{C}$, Tooth structure is conserved by uprighting a tilted FPD abutment.

\section{Margin Placement}

The margin of the preparation should be supragingival whenever possible. Subgingival margins of cemented restorations particularly when they encroach on the epithelial attachment have been identified as a major factor in periodontal disease [17]. Supragingival margins can be situated on hard enamel, and are easier to prepare accurately without trauma to the soft tissues. They can usually whereas subgingival margins are often on dentin or cementum.

\section{Margin Adaptation}

Because of the dissolution of luting agent and inherent roughness of the cement, the junction between a cemented 
restoration and the tooth is always a potential site for recurrent caries The more accurately the restoration is adapted to the tooth, the lesser the chance of recurrent caries or periodontal disease [18]. Although a precise figure for acceptable margin adaptation is not available, a skilled technician can make a casting that fits to within $10 \mu \mathrm{m}$ [19], and a porcelein margin that fits to within $50 \mu \mathrm{m}$ [20], provided the tooth is properly prepared.

A well-designed preparation is characterized by the presence of a smooth and even margin. Rough, irregular, or "stepped" junctions significantly increase the length of the margin and substantially reduce the adaptation of the restoration (Fig. 9).

\section{Occlusal Considerations}

A satisfactory tooth preparation should allow sufficient space for developing a functional occlusal scheme in the finished restoration.

\section{IMPRESSIONS}

An impression must provide thorough information about the prepared teeth, surrounding teeth, and associated soft tissues. The impression must record the form of all prepared surfaces and some of the unprepared tooth cervical to the finish line. Impression making of tooth preparations that extend subgingivally with an elastic material is likely to damage the soft tissues.

It is important to avoid damage to the gingival sulcus and junctional epithelium in the course of tooth preparation, gingival retraction, and impression taking. When a completecoverage crown restoration is performed, the chances for damaging the periodontium is particularly more. The histological components of the periodontium shows, that the alveolar crest is covered by the supracrestal fiber complex (Sharpey's fibers), the junctional epithelium, and the gingival sulcus. The sulcus is very limited in depth - less than $1 \mathrm{~mm}$ in a healthy periodontium. The sulcular epithelium is non-keratinized. The dento gingival junction (biologic width) seals the underlying connective tissue of the periodontium from the oral environment [21].
Iatrogenic disruption of the junctional epithelium may cause an inflammatory lesion in the gingival corium and fiber apparatus. This can lead to gingival recession, migration of the junctional epithelium, and permanent bone loss [22]. The retraction cords may harm the attachment apparatus if they are tightly packed for a prolonged period (i.e. more than five minutes). If the inflamed gingiva is retracted, it may result in permanent loss of attachment [23]. In other cases, the application of a retraction cord may be impossible when the gingival sulcus is damaged by perodontitis or a faulty restoration. (Fig. 10).

To summarize, any impression procedure must consider the delicacy of the junctional epithelium and attachment of the supra crestal fibers and take safety measures not to disturb them [24]. Adequate gingival retraction is necessary for impression making. The use of retraction cord has proved to be an effective method of soft tissue management. Injury to sulcular epithelium may be caused by placement of retraction cord and cotton strings into the gingival sulcus. The trauma caused to the soft tissue depends upon the chemical agent with which the cord has been impregnated, the force used in packing the cord and the length of time the cord is left in place within the sulcus. To avoid forcing the cord into the sub-epithelial connective tissue the force used to place the cords should be minimal. Most importantly prior to its removal, the cord should be moistened to avoid tripping the sulcular epithelium [25].

For margins placed intra-crevicularly, impressions are more difficult to obtain as it requires displacing the free gingival tissues. Injudicious use of gingival retraction techniques causes injury to the biologic width and permanent alterations such as recession. Careful considerations for the tissues are required during crown preparation and impression making. If tube impressions are made, then the individual tubes should be carefully adapted and should relate accurately to the gingival line. Excessive digital force causes stripping of the gingiva. Gingival retraction cords used should not have excess diameter as any undue force during cord placement also causes damage to the attachment. Special precautions should be taken for thin and delicate gingival tissue and where attached gingiva is inadequate as undue insult to the tissues can cause recession. When placing cord

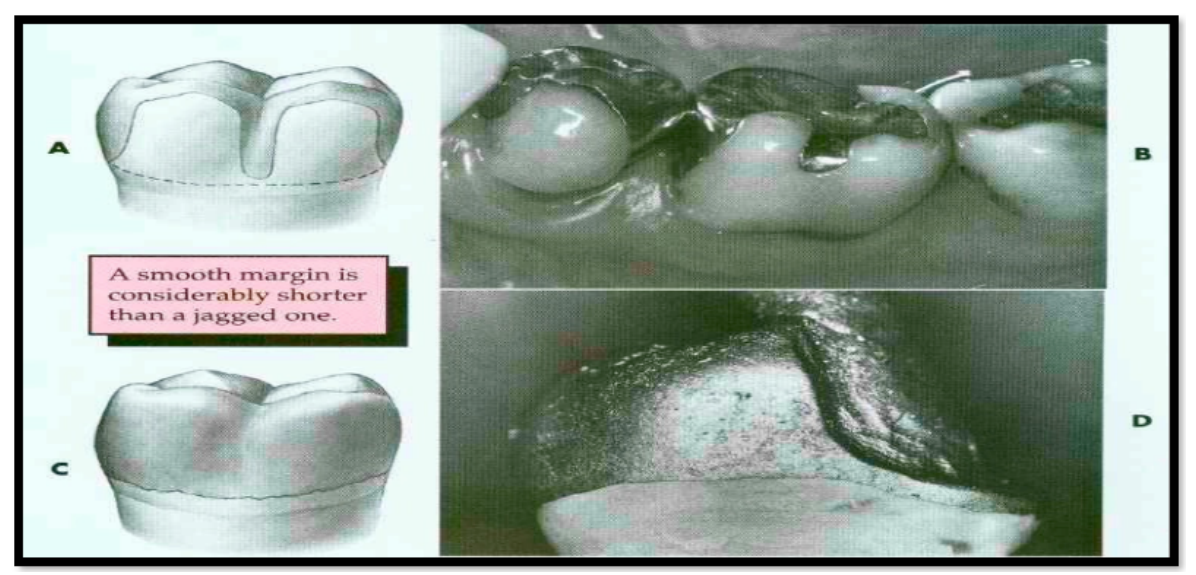

Fig. (9). A and B, Poor preparation design, leading to increased margin length. C, A rough, irregular margin will make the fabrication of an accurately fitted restoration almost impossible. D, An accurately fitting margin is possible only if it is prepared smoothly. 
into the sulcus when excessive instrument pressure is applied it can cause extensive gingival tissue damage and recession [26].

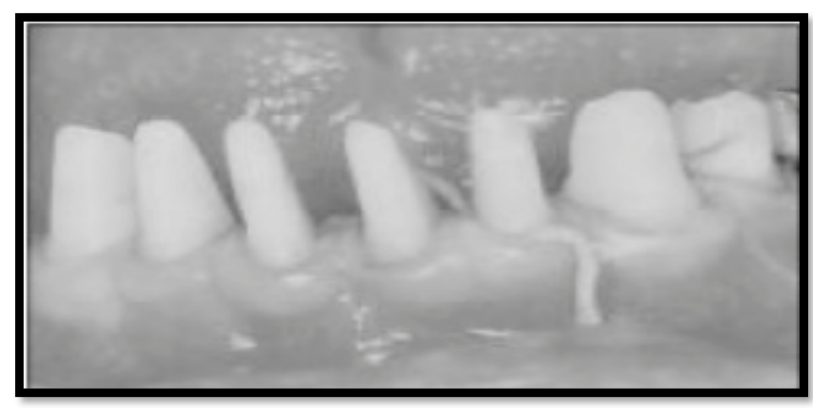

Fig. (10). Gingival retraction may be impossible, due to a shallow sulcus.

\section{Temporary Coverage (Temporary Crowns)}

Temporary crowns done in haste without considerations for the periodontium causes disturbances that may result in permanent damage. Factors are

1. Over extended temporary crowns. -Causes gingival hyperplasia or recession if attachment has been injured severely. Damage could be in the inter dental regions or in facial and lingual marginal areas

2. Under extended temporary crowns. -Contribute to hypersensitivity by interfering with adequate oral hygiene measures.

3. Poor proximal - contact relationships. -Contribute to food impaction and retention and to the drifting of the approximated teeth. If the finishing of the temporary coverage is uniformly poor then plaque constantly accumulates inspite of patient trying to keep good oral hygiene. Temporary coverage is mainly given to protect the prepared teeth and promote gingival healing.

\section{Contours of Full Crown Restorations of Teeth Uncompli- cated by Recession}

Occlusal morphology: The effect of occlusion on the periodontium has been a topic of discussion among dentists, and periodontists in particular. Since the beginning of this century, debate has raged over the years regarding the influence or lack of influence of occlusal trauma on periodontal disease. Early studies without adequate controls implicated occlusal trauma in the formation of pockets and as the cause of gingival recession. Contemporary studies with adequate controls that limit variables have produced more objective data on occlusal trauma and its effect on the periodontium [27].

The ability to link the clinical presentation and the biologic and histo-pathologic entity is the basis for clinical understanding and appropriate treatment planning. Any force applied to a tooth, whether a unilateral orthodontic-type force or a bilateral tooth-to- tooth "jiggling" force, has the potential to produce a pathologic effect on the attachment apparatus (cementum, periodontal ligament. and bone). The pathologic lesion in the attachment apparatus that is established by trauma from force (occlusal trauma) causes a loss of alveolar and crestal lamina dura and resultant widening of the periodontal ligament space. Clinically over a period of time the occlusal traumatic lesion in the attachment apparatus presents increasing tooth mobility [28].

\section{Correct Occlusal Anatomy}

Occlusal surfaces must be directed along the longitudinal axis of teeth. Cuspidian slopes of an improperly modeled restoration in relation with the opposite tooth can produce widening of the contact point during functional movements. This allows inter-dental impaction of foodstuff, with detrimental effects on inter-proximal periodontal tissues. Marginal occlusal ridges must be placed above the proximal contact surface, and must be rounded and smooth so as to allow the access of dental floss.

\section{Correct Proximal Anatomy}

Proximal surfaces and dental crowns must be divergent, beginning from the contact area towards vestibular direction, orally and apically. Proximal surfaces be smooth and polished and the inter-dental contact area must be properly made, in order to prevent inter-dental food lodgment.

\section{Location of Contact Point}

Discrepancy of the inter-proximal contact surface causes food retention, gingival inflammation, pocket formation, bone loss and finally tooth mobility. The most common cause of chronic gingivitis and periodontitis is food lodgment.

\section{These Following Factors are Significant}

The contact surface in a lateral tooth must be located at 1-2 $\mathrm{mm}$ below the greatest height of the marginal ridge; it should not exceed 1-2 $\mathrm{mm}$ in length in occluso-gingival direction and it should measure approximately $25 \%$ of the orovestibular width of the neighboring tooth; - in the upper arch the contact surface is situated slightly towards the vestibular area, from the median mesio-distal line and in the lower arch is located on the median line;- the contact surface enlarges with patient's aging.

Vestibular and oral surfaces: These surfaces, if well proportioned, play an important role in maintaining gingival health.

Under-contoured vestibular and oral surfaces: They may alter the normal path of food and cause its filling and accumulation in the gingival groove.

Over-contouring will deflect food beyond the marginal gingiva, reaching the attached gingiva. This fact removes the marginal gingiva of self-cleaning mechanical action of food, which can stagnate in over protected gingival groove.

\section{CONCLUSION}

The principles of tooth preparation can be categorized into biologic, mechanical, and esthetic considerations. Often these principles conflict and the practitioner must decide how the restoration should be designed. One area may be given too much emphasis, and the long-term success of the 
procedure may be limited by a lack of consideration of other factors. Experience will help in determining whether preparations are "complete." Each tooth preparation must be measured by clearly defined criteria, which can be used to identify and correct problems. Diagnostic tooth preparations and evaluative impressions are often very helpful. Successful preparation can be obtained most easily by systematically following the steps. It is critical to refrain from "jumping ahead" before the previous step has been evaluated and, if necessary, corrected. If the clinician proceeds too rapidly, precious chair time will be lost, and the quality of the preparation will probably suffer.

\section{CONFLICT OF INTEREST}

The authors confirm that this article content has no conflict of interest.

\section{ACKNOWLEDGEMENTS}

Declared none.

\section{REFERENCES}

[1] Baldissara P. Clinical and histological evaluation of thermal injury thresholds in human teeth: a preliminary study. J Oral Rehabil 1997; 24: 791-801.

[2] Ohashi Y. Research related to anterior abutment teeth of fixed partial denture. Shikagakuho 1968; 68: 726.

[3] McKee JR. Comparing condylar position respectability for standardized versus non standardized methods of achieving centric relation. Prosthet Dent 1997; 77: 280.

[4] Gargiulo AW, Wentz FM, Orban B. Dimension and relations of the dentogingival junction in humans. J Periodontol 1961; 32: 262.

[5] Parma-Benfenati S, Fugazzoto PA, Ruben MP. The effect of restorative margins on the postsurgical development and nature of the periodontium. Part I. Int J Periodont Rector Dent 1985; 6: 31.

[6] Olsson M, Lindhe S. Periodontol characteristics in individuals with varying forms of the upper central incisors. J Clin Periodontol 1991; 18: 78 .

[7] Ingber JS, Rose LF, Coslet JG. "The biologic width": a concept in periodontics and restorative dentistry. Alpha Omega 1977; 70: 625.

[8] Maynard JG, Wilson RDK. Physiologic dimensions of the periodontium significant to the restorative dentist. J Periodontol 1979; 50: $170-4$.
[9] Gargiulo AW, Wentz F, Orban B. Dimensions and relations of the dento-gingival junction in humans. J Periodontol 1961; 32: 261-7.

[10] Nevins M, Skurow HM. The intra-crevicular restorative margin, the biologic width, and the maintenance of the gingival margin. Intl J Periodont Restor Dent 1984; 3: 31-49.

[11] Block PL. Restorative margins and periodontal health. A new look at an old perspective. J Prosthet Dent 1987; 57: 683-9.

[12] Vacek JS, Gehr ME, Asad DA, Richardson AC, Giambarresi LI. The dimensions of the human dento-gingival junction. Int J Periodont Restorat Dent 1994; 14: 154-65.

[13] Sorensen JA. A rationale for comparison of plaque-retaining properties of crown systems. J Prosthet Dent 1989; 62: 264.

[14] Perel ML. Axial crown contours. J Prosthet Dent 1971; 25 : 642.

[15] Baldissara P. Clinical and histological evaluation of thermal injury thresholds in human teeth: a preliminary study. J Oral Rehabil 1997; 24: 791.

[16] Ohashi Y. Research related to anterior abutment teeth of fixed partial denture. Shikagakuho 1968; 68: 726.

[17] Silness J. Periodontal conditions in patients treated with dental bridges. III. The relationship between the location of the crown margin and the periodontal condition. J Periodont Res 1970; 5: 225.

[18] Felton DA. Effect of in vivo crown margin discrepancies on periodontal health. J Prosthet Dent 1991; 65: 357.

[19] Byrne G. Casting accuracy of high palladium alloys. J Prosthet Dent 1986; 55: p. 297.

[20] Belser UC. Fit of three porcelain-fused to metal marginal designs in vivo: a scanning electron microscope study. J Prosthet Dent 1985; 53: 24 .

[21] Berkowitz BKB, Holland GR, Maxham BJ. Colour atlas and textbook of oral anatomy. Wolfe Med Publ Ltd 1978; pp. 129-32.

[22] Wilson RD. Restorative dentistry. In: Wilson TG, Kornman KS, Newman MG, Eds. Advances in periodontics. Chicago: Quintessence Publ Co Inc 1992; pp. 226-30.

[23] Wise MD. Tooth preparation, gingival retraction, hydrocolloid technique, master cast systems, soldering. In: Failure in the restored dentition: management and treatment. London: Quintessence Publ Co Ltd 1995; pp. 189-90.

[24] Nevins M, Cappetta EG. The biologic width: preventing postsurgical recession. In: Nevins M, Mellonig, Eds. Periodontal therapy, clinical approaches, and evidence of success. Chicago: Quintessence Publ Co Inc 1998; 1: pp. 305-7.

[25] Kois J, Vakay RT. Relationship of the periodontium to impression procedures. Compend Contin Educ Dent 2000; 21: 684-90.

[26] Benson BW, Bomberg TJ, Hatch RA. Tissue displacement methods in fixed prosthodontic. J Prosthet Dent 1986; 55: 175.

[27] Svanberg G. Lindhe J. Experimental tooth hyper mobility in the dog. Odontol Rev 1973; 24: 269.

[28] Meitner S. Co-destructive factors of marginal periodontal disease and repetitive mechanical injury. J Dent Res 1975; 54: 78.

Received: December 22, 2014

Revised: March 04, 2015

Accepted: March 10, 2015

(C) Harish et al.; Licensee Bentham Open.

This is an open access article licensed under the terms of the Creative Commons Attribution Non-Commercial License (http://creativecommons.org/licenses/by-nc/3.0/) which permits unrestricted, non-commercial use, distribution and reproduction in any medium, provided the work is properly cited. 